\title{
On Stigmata, Suffering and Sanctity
}

\author{
Tine Van Osselaer
}

On 2 May 1910, Theodor Nolde from Buer (Westphalia in Germany) sent a letter to the episcopal office of Liège in Belgium. About three weeks before, he had travelled to Lummen in Belgium in order to witness the stigmatized Rosalie Put (1868-1919, stigmata 189o) suffer through Christ's Passion. He had seen her wounds and her ecstasy and, as he wrote, was "deeply moved by the suffering of Rosalie Put and found religious edification while there." He believed Rosalie to be divinely inspired ("gottbegnadeten Person") and wanted to ask the Bishop of Liège whether or not the Church really thought her to be a fraud, or even diabolical ("teuflisches Weib"), as he had heard. ${ }^{1}$ Nolde explicitly described his visit as an edifying experience, but how could this be the case? Why would a Catholic such as Theodor Nolde want to see someone suffer through Christ's Passion in the first place? This chapter addresses the appeal of the stigmatic's suffering, and studies the ways in which devotees viewed the stigmatic's body in pain. What did the suffering of stigmatics mean to them? ${ }^{2}$

Rosalie Put's profile fits that of a typical stigmatic: she was a young woman who carried visible wounds and suffered through Christ's Passion in the presence of numerous visitors in a domestic setting. This chapter focuses primarily on the reception of such stigmatics in regions of Germany and Belgium. This geographical focus allows us to explore reports on stigmatics from the different waves we have detected, as well as look at some of the earliest examples (e.g. Anna Katharina Emmerick, 1774-1824, stigmata 1812). While we do not want to underestimate the importance of the specific historical contexts of these cases (i.e. assume that late nineteenth-century Belgian Catholicism and early twentieth-century German Catholicism provide the same background), we

1 “[... und war dem leidenden Zustand der Rosalie Pütt tief ergriffen und habe mir dort religiöse Erbauung geholt. Ich halte die Rosalie Pütt für eine gottbegnadeten Person." Archives de l'évêché de Liège (AEL), Rutten, Varia 284, Le cas de Rosalie Put, letter of Theodor Nolde, 2 May 1910.

2 On the role of religion in the interpretation of the body, see among others, McGuire, "Why bodies matter," 290; De Soucey et al. "Memory," 102. On the importance of the body in Catholic culture, see Corbin, "L'emprise," 54. 
believe that in relation to perceptions of pain and suffering, the reports on the stigmatics reveal some similarities.

An event that involves staring at a woman's body in the confines of her private, domestic sphere (bedroom), calls for a reflection on ideas of gender, corporeality and devotion. ${ }^{3}$ We will show that the interest in visiting stigmatics, ${ }^{4}$ witnessing their Passion and evaluating the visit as a religiously edifying experience, can only be understood if we take into account the shifting perceptions of pain and try to see how the faithful of the nineteenth and early twentieth century read a suffering body. ${ }^{5}$ The bloody physical wounds were not only a sensational feature, drawing the attention of the curious, but also served as potential "proof" of God's intervention. By focusing on the faithful's pious devotion to the stigmatics' suffering and their wounds, we do not want to imply that the Catholic response was unanimously positive. Not everyone "believed" in the stigmatics, and the possibility of fraud, illness and diabolic intervention was left open. ${ }^{6}$ In the following, we will first address the issue of the visibility and interpretation of the wounds and suffering, showing how these were linked to perceptions of the miraculous ${ }^{7}$ and how the body of the stigmatic was set apart as a special body. We will then link these perceptions to the interpretation of pain, and the culture and gender of suffering, examining what effect such visits could have on the devotees.

\section{The "Spectacle" of the Holy Wounds}

\subsection{Visibility of the Stigmata}

Let us return to Nolde's letter about Rosalie Put cited above. While Nolde kept the description of his visit to the minimum, one thing he did deem necessary to mention was: "I saw the stigmatized wounds and ecstasy, attended

3 Waltraud Pulz points to work on the intersection of the history of religion and the history of the body in the Middle Ages, and she calls for more research on the vitalization and reinvention of corporeal devotional practices in the nineteenth century, Pulz, "Vorbemerkung," 12.

4 For a more general reflection on visits to stigmatics, see Chapter 4.

5 Rather than focus on the autobiographical writings (letters and diaries) of the stigmatics about their pain and visions of Christ's Passion, this chapter addresses the experience of the visitors and the ways in which the suffering of the stigmatics was perceived by Catholic contemporaries. However, in focusing on the perceptions of the visitors, we do not intend to reduce the stigmatics to mere objects of observation with no agency. We agree with Monique Scheer that their patient suffering and acceptance of their pain and illnesses could have been empowering, and thus, a form of agency, Scheer, "Das Medium," 182.

6 Weiß, "Stigmata," 124.

7 See also, Pahud de Mortanges, "Fromm," 172. 
the well-known events and was deeply moved by the suffering of Rosalie Put and found religious edification while there." ${ }^{\prime}$ For Nolde, the physical and visible phenomena - the stigmata, ecstasy and suffering - were enough to convince him that she was divinely inspired. He does not elaborate any further on Rosalie's biography. As we will see, Nolde was not the first nor the only one to leave with this conviction.

The visibility of Put's stigmata is of central importance here. As the previous pages have shown, stigmata were not a new feature in the early twentieth century. Since the attestation of St Francis' $(1181-1226,1224)$ wounds in the early thirteenth century, stigmata have been reported throughout the eras. However, stigmatization did not always entail the materialization of the physical wounds. As the Franciscan-Dominican debates on the stigmatization of Catherine of Sienna $(1347-1380,1375)$ have shown, the wounds need not become visible. ${ }^{9}$ What exactly these physical 'wounds' were also varied. While some stigmatics bled from their hands and feet (marks of the crucifixion), others also showed traces of the crown of thorns, flagellation and bruises on their shoulder (on which Christ had carried the Cross). ${ }^{10}$ Some of these bloody marks were not an imitation of Christ's wounds, but figurative (such as a Y-shaped cross) ${ }^{11}$ or implied sweating or crying blood.

Carrying the visible wounds did not mean one was willing to show them to others, and St Francis took great care to hide the signs of his corporeal imitation of Christ. ${ }^{12}$ The idea of hiding stigmata as a sign of humilitas also echoes through our sources from the modern era. The biographies of the nineteenth and twentieth-century stigmatics that we study frequently mention how the stigmatic prayed for the physical signs to disappear. These stigmatics only

8 "Ich habe die stigmatisierten Wunden und die Extase gesehen und den Ihnen jedenfalls hinlänglich bekannten Vergnügen beigewohnt und war dem leidenden Zustand der Rosalie Pütt tief ergriffen und habe mir dort religiöse Erbauung geholt. Ich halte die Rosalie Pütt für eine gottbegnadeten Person," Archives de l'évêché de Liège, Rutten, Varia 284, Le cas de Rosalie Put, letter of Theodor Nolde, 2 May 1910.

9 Adnès, "Stigmates," c.1225. On the debate about the stigmata of Catherine of Sienna, see Bouflet, Les stigmatisées, 36; Jungmayr, "Ekstase," 71-74; Herzig, "Stigmatized Holy Women," 156.

10 Bouflet, Les stigmatisés, 69.

11 See the image of the stigmata of Anna Katherina Emmerick, preserved in Leuven, Kadoc, Archief van de Jezuïeten. Belgische en Vlaamse Provincie. 4.2.1.9. Archief van het provinciaal bestuur. Spiritualiteit en devotioneel leven, 2261: A.K. Emmerick.

12 Vinken, "Via crucis," 18, who contrasts this with the theatricality of martyrdom (that St Francis initially wished for himself) and asceticism. 
wanted to feel the pain of the "invisible"/"interior"13 stigmata (on their hands and feet, side and head) and participate in Christ's Passion, they did not want to draw attention to themselves. ${ }^{14}$ Nevertheless, displaying the wounds could also be interpreted in a positive way - as a sign of humility. Joachim Bouflet has noted that the female stigmatics of the Rheno-Flemish region, who succeeded Poverello in the thirteenth and fourteenth centuries, saw their visible stigmata as an opportunity for the edification of others. Their humility lay in their acceptance of being put on display. ${ }^{15}$

The high number of stigmatics carrying the visible wounds in the nineteenth century requires reflection, since it stands in stark contrast with the increasing distrust of visible stigmata in the previous centuries. As Antoinette Gimaret has noted, beginning in the seventeenth century, stigmata were increasingly contested as a sign of sanctity. They were regarded as too ambiguous, since they could be manipulated and imitated by false saints. ${ }^{16}$ The pain that the stigmatics suffered was deemed more important than the physical signs; or, as Gimaret noted, "what was stigmatized was not the excess of devotion, but its spectacular expression."17 Xenia von Tippelskirch commented on this diminishing importance of the visibility of the wounds in her work on reports of stigmatization in France 1630-1730, postulating that this in fact

13 Joachim Bouflet prefers this term, Bouflet, "Les stigmates," 147. On the topos of humilitas, see von Tippelskirch, "Ma fille," 264.

14 AEK, Generalia I. 31. Religiöse Umtriebe, letter of Wilhelm Schrammen, the vicar of Giesenkirchen, "Bericht über die Eindrückung der Wundmale unseres Herrn Jesu Christi" (Charsamstag 1852).

15 Bouflet cites the Beguine Gertrude van Oosten (+ 1358), "J'accepterais d'être exposée en spectacle $[\ldots]$ de façon que tous puissent voir les signes des merveilles divines et qu'en les voyant ils louent et glorifient Dieu." Acta sanctorum, Anvers, 1643, janv. T.I, 352, Bouflet, Les stigmatisés, 31 .

16 Gimaret, "Corps marqués," 24: "Le siècle manifeste en effet une suspicion grandissante envers les signes visibles de la piété, considérés comme trop ambivalents car manipulables et reproductibles par des saints de fiction, comme le révèlent certains cas de 'sainteté simulée' mis en avant dans les tribunaux civils et religieux dès la fin du Xvi ${ }^{\text {ème }}$ siècle," 257. There was a double danger linked to stigmata: if they were invisible, they could be doubted; if they were visible, their appearance might be reduced to a purely medical explanation.

17 Gimaret, Extraordinaire, 211: “Ce qui est stigmatisé n'est donc pas l'excès de dévotion, mais son expression spectaculaire." Gimaret shows how this distrust stands in stark contrast with the situation at the start of the seventeenth century when, under the influence of the Counter-Reformation and the "mystic invasion," the suffering bodies of the martyrs (of the religious wars) and the mystical religious featured prominently in hagiographic accounts (14-16). However, in Italy, the first trials of "feigned sanctity" in 1580-1590 stimulated an increasing marginalization of the miraculous in the process of canonization (202). 
suggests a change in the status of pain. Reflecting on the emotional and corporeal outcomes of the meditation on Christ's suffering, she noted that even the "inner" experience of pain could be visible and witnessed by others (e.g. in cries of pain). In the seventeenth century, pain could have a signalling function ("Zeichencharacter") that could surpass even the bleeding wounds. ${ }^{18}$ Reports on visible stigmatization also remained relatively rare in the eighteenth century. Under the influence of Enlightenment tendencies, the Catholic Church regarded the "miraculous" phenomena - including stigmatization with distrust. ${ }^{19}$

Thus, how can we explain the upsurge in visible stigmata during the nineteenth century? Two elements seem to have been of importance here. First of all, the nineteenth century witnessed a reappraisal of the "miraculous" by the Catholic clergy and Church, which started to exhibit a more positive attitude towards popular piety (e.g. veneration of relics). ${ }^{20}$ Nils Freytag and Diethard Sawicki have noted that the ultramontane Catholicism of the period was also characterized by an "almost obsessive craving for physical proof of the direct intervention of angels and demons in our world."21 A second element of importance was the influence of developments within the medical field. As experimental, or scientific proof, gained validity, "visible" signs of the supernatural

18 Pain needs to be witnessed, as it can be a sign of sanctity, von Tippelskirch, "Schmerzen," 163.

19 Weiß, "Stigmata," 115. There were, of course, still cases reported, see, for example, the work of Lutz-y-Graf on the stigmatized Dominican nun from Hadamar, Magdalena Lorger ("Das Wunder im Dorf," 239). Gabor Klaniczay discusses a case of alleged sanctity linked to the stigmatization of Serafina Vincenti (1739, Florence) and mentions how at that time three examinations concerning the canonization of a stigmatic were ongoing. Klaniczay, "Louise Lateau," 279-28o. Bouflet refers to several cases in the archives of monastic orders, Bouflet, Les stigmatisés, 73.

$20 \quad$ Ford, Divided Houses, 102; Clark, "The new Catholicism," 11, 17. Weiß called it symptomatic of the crisis of modernity in Catholicism in the nineteenth century. Faced with the challenges of the secularizing world, they sought shelter in the safety of what they thought was mysticism, Weiß, "Stigmata," 117-118. There was a new turn towards the supernatural, and not only within Catholicism in contrast to scientification, objectification, historicism and positivism. Priesching, Maria von Mörl, 17, links this to the rejuvenation of Baroque forms of piety and (for the Tyrolean case) a new generation of priests who trained at the recently reopened priest seminars.

21 "[...] einer fast schon obsessiven Begierde nach physisch greifbaren Beweisen für das direkte Hineinwirken der Engel und Dämonen in unsere Welt," Freytag and Sawicki, "Verzauberte Moderne," 17. Lachapelle, "Between miracle and Sickness," 79, "spiritual beliefs made tangible through physical evidence of the supernatural. Stigmatics, ecstatics, visionaries, and miraculously cured persons [...]." Kane, "Stigmatic cults," 106, "The desire for faithful Catholics to defeat secularists by constantly reaffirming the existence of the supernatural took high and low cultural forms [...] at the popular level, an explosion of reports of apparitions, miraculous cures, and stigmata, fed the taste for marvels." 
became more important. ${ }^{22}$ As these were phenomena that could be tested and rejected by the enemies of the Church, mystical epiphenomena such as visible stigmata became the focus of attention.

The Church called on experts to confirm or reject the authenticity of the wounds, or detect instances of fraud and simulation, which Barbara Vinken aptly described as "the inclusion of stigmata in the register of experimental research." ${ }^{23}$ Otto Weiß links this call for factuality - empirically provable signs of God's intervention on earth - to the rise of historicism and positivism. ${ }^{24}$ In his history of stigmatization, Joachim Bouflet mentions how trajectories such as those of Francis of Assisi and Catherine of Siena had become the exceptions. No longer miraculous signs of the transformation of a soul, stigmata were perceived as sensational epiphenomena, "proof" of the authenticity of a spiritual experience, which many stigmatics were happy to exhibit. This "tendency towards exhibitionism went hand in hand with the theatricalization of ecstasy." 25

The need for physical, visible - even tangible - proof and the central importance of the wounds in the reception of the stigmatics are amply documented in the testimonies of the faithful who saw them. A visitor to the famous German stigmatic, Anna Katharina Emmerick (1774-1824, stigmata 1812), described how he left "believing in the wounds" ("an die Wundmale glaubend") after a visit in 1812:

When we arrived, she was completely in ecstasy [...] she looked as if she was dead. The Pater told me to take her hand, which I did, and I saw that her hand bled from her wounds and I felt they were ice cold. My brother, the Pater, revealed her chest and I saw the cross on her chest, more or less in the shape of the cross of the Lamberts church in Coesfeld. I saw the side wound and the bloody water that oozed out of the wound in small drops. ${ }^{26}$

22 von Tippelskirch, "Schmerzen," 149 and "Ma fille," 274-77. On this visibility as "proof," see Albert, Le sang, 206. It was a period in which the divine became tangible in corporeal phenomena, a mystical era populated by stigmatics, ecstatics and visionaries, Lachapelle, "Between miracle and Sickness," 79.

23 "die Einfügung der Stigmata in das Register experimenteller Forschung," Vinken, "Via crucis," 21, see also Menke, "Mund," 273 and Brandstetter, "Reliquienberg," 246.

24 Weiß, "Seherinnen," 62 and 75 .

25 "[...] tendance à l'exhibitionnisme, qui va de par avec la théâtralisation de l'extase," Bouflet, Les stigmatisés, 39 .

26 "Ich war aber sehr bewegt und ging an die Wundmale glaubend nach Hause" [...] "Als wir ankamen, war sie ganz in Verzückung, [...] Sie sah so aus, dass sie ich glaubte, sie sei tot. Der Pater sagte mir, ich sollte sie einmal bei der Hand fassen, welches ich dann auch that, und ich habe gesehen, dass die Hände an den Wundmalen blüteten und fühlte, das 
Visitors to the nineteenth and early twentieth-century stigmatics wanted to see blood - or so it seems. The importance of bloody wounds is amply illustrated by the story of Maria Fiechtner (1808-?). When she started to experience ecstasies on Fridays in 1839, she drew little attention. In 1841, her pastor commented on how she had managed to remain unknown. Only three priests had seen her in ecstasy, reliving the Passion, but there was no wonder to be seen, he asserted, adding that the world "wants blood" ("will Blut haben"): "As it is, only a small number of people will find there is something to see that might trigger their admiration." ${ }^{27}$ He preferred to keep things quiet. Bloody wounds were the culmination of what could be a series of preliminary phenomena (fits, feeling pain), and the wounds were a point of attraction to the visitors. ${ }^{28}$

In the case of Anna Perschl from Tyrlbrunn (stigmata 1840), the priest who had exorcised her and told her about famous stigmatics such as Anna Katharina Emmerick and Maria von Mörl "asked eagerly if she did not yet feel the wounds that would inevitably develop, as was the case with other people. He examined her hands in order to obtain what for him was so joyful a certainty. In that way, he was the one who gave the peasant folk the idea to let the wounds appear."29

sie eiskalt waren. Mein Bruder, der Pater, öffnete ihr die Brust und ich habe ein Kreuz auf ihrer Brust gesehen, ungefähr in der Form wie das Kreuz in der Lambertskirche zu Coesfeld. Ich habe die Wunde in der Seite gesehen und das blutartiges Wasser in kleinen Tropfen aus der Wunde kam, habe ich gesehen," BAM, Emmerick/Hensel, 40. Stimmen, testimony of Franz Limberg $\left(1785^{-1867}\right)$, he wrote his testimony (on his own initiative) in 1858 .

27 "Ohnehin ist dabei für die wenigsten Menschen etwas zu sehen, was ihre Bewunderung in Anregung bringen könnte," Archiv des Erzbistums München und Freising (AEM), Realia 923a, Erscheinungen-Einzelfälle, 1839-1845, Ausserordentlicher Zustand der Elisabeth Bartenhauser aus der Pfarrey Gaisach (Bartenhauser), Letter of Weinzierl to his Archbishop, 6 October 1841. It was only when cases such as that of Teresia Taubenberger, who was from the same region, started to draw attention that her case appeared once again.

28 This is similar to Görres's idea about full stigmatization (first the crown of thorns, side wound and then gradually the other wounds), Görres, Die christliche Mystik, 410-411; on Emmerick see, 453. A similar system of different phases in mystical phenomena (the ideas on mysticism of the Jesuit Giovanni Battista Scaramelli [1687-1752] in Il direttorio mistico were published in German in 1855) played a role in the evaluation of Maria von Mörl. Priesching, "Mystikerinnen," 9o.

29 " [...] fragte [...] sie fleißig ob sie dann die Wundmalen noch nicht in sich verspüre, die ja notwendig kommen mussten, wie bei den obrigen Personen. Er untersuchte ihre Hände um sich die für ihn so freudige Gewissenheit zu verschaffen. So war er es der die Lenzbauernleute auf der Gedanke brachte, auch die Wundmale erscheinen zu lassen." AEM. Realia 923 a. Erscheinungen - Einzelfälle 1839-1845. 1840 Auffallende Erscheinungen an der Bauertochter Perschl zu Tyrlbrunn betr. (Perschl), Letter from the chaplain of the hospital in Munich (to which Anna Perschl was brought) to the Archbishop, 19 May 1840. 
When Anna finally showed the physical signs, the response was impressive. In a letter to the Archbishop, a local pastor complained: "People flood in from all sides, partly out of curiosity, partly out of religious zeal towards Perschl, as if to a cult statue; they admire her and see her, if not as a complete then as a demi-saint." ${ }^{30}$ In other words, the wounds were not only seen as a sign of divine intervention, they seem to have been linked to a perception of sanctity in which the saint functions as a revelatory token rather than as someone leading an exemplary Christian life. ${ }^{31}$ A similar comment made by a fellow parishioner about Barbara Pfister, a late nineteenth-century stigmatic from Wattenheim, on seeing her around Christmas 1892: "The image remained as a truthful memory, how she lay there bleeding from her head, hands and feet, trembling and shaking, absent minded. I thought, that is a saint." ${ }^{\prime 2}$

\subsection{Spectacle: The Visibility of the Stigmatic}

Anna Katherina Emmerick (stigmata 1812), Anna Perschl (stigmata 1840) and Rosalie Put (stigmata 1890) all displayed the visible stigmata and received visitors who thought them special because of these wounds. In this respect, it is important to remember that this type of stigmatic differed from others. A report written in 1869 on two Belgian stigmatics may help to elucidate this aspect. The text compares the case of an anonymous stigmatized Carmelite nun from Tournai (stigmata 1851) with that of Louise Lateau (1850-1883, stigmata 1868), probably one of the most famous stigmatics in Europe at the time. The author notes that while the wounds displayed by the two women were similar, "what occurred during their moments of ecstasy was quite different. In Lateau's case there was an impressive scene-setting, full of emotions

30 "Von allen Seiten strömen Leute, theils aus Neugierde, und theils aus religiösen Eifer getrieben, zur Perschl wie zu einem Gnadebilde herbey, bewundern sie, sehen sie, wo nicht für eine ganze, doch für eine halbe heilige an," АЕM, Realia 923a, Erscheinungen - Einzelfälle 1839-1845, Perschl, letter of Pfarrer Joseph Ostner to the Archbishop, 29 February 1840, 2 and 3.

31 For the difference between this bottom-up perspective on sanctity and the official stance, see Woodward, Making Saints, 158. For the Vatican response to stigmatics and the ways in which some managed to attain official sanctity (beatification, canonization), see Chapter 7 in particular.

32 "Das Bild blieb mir in treuer Erinnerung, wie sie blutend an Kopf, Händen und Füssen dalag, zitternd und bebend, geistesabwesend. Ich dachte, das ist eine Heilige," Archiv Bistum Speyer (ABSp), Dokumentation Barbara Pfister Karton 1-6, S5, M8 Befragungen von Pfarrangehörigen aus Wattenheim, Frau Balthasar Matheis (part of a series of testimonies, 1938-1939). 
for the onlookers; more than once someone uttered the word "miraculous'." 33 The suffering of the Carmelite nun, on the contrary, took place in an enclosed setting and there seem to have been no spectators. "Scene-setting" ("mise en scene") and "onlookers" ("spectateurs") are the key words in the description of Lateau. It is this type of visibility, not that of the wounds - both of the women had visible stigmata - but that of the suffering and its public character that needs to be addressed here. The majority of the stigmatics who were reported in the nineteenth and early twentieth century, were not living in a cloister hidden from view or bound to a vow of silence about the phenomenon. ${ }^{34}$ They were experiencing this in their family homes - domestic theatres of religious "spectacle." Nevertheless, we should be careful in presenting this visibility as a completely new phenomenon. The Dominican tertiary, Lucia Brocadelli (1476-1544; stigmata 1496), who bled in "a rhythmic pattern every Friday, the day commemorating Christ's crucifixion, when the pains that she felt were particularly strong," also attracted visitors. ${ }^{35}$ Thus, such regular public suffering can already be found in the fifteenth century. Interestingly, the "nun Lucia of Ferrara" was also mentioned in one of the articles written in 1817 concerning Anna Katherina Emmerick, indicating that the contemporaries of the famous nineteenth-century stigmatic also saw similarities with the Italian case. ${ }^{36}$

In addressing stigmatization as a "spectacle," the following discussion draws on Sigal Gooldin's approach to Victorian fasting women, a phenomenon that, like stigmatization, has been reported since the High Middle Ages, and which also bloomed again in the nineteenth century. Gooldin emphasizes that we need to distinguish between the "act" of fasting and the "spectacle" of fasting, "the appeared, performed, visible, 'gazed at' phenomenon of fasting" (interpreted by the spectator). ${ }^{37}$ Each person who observed a fasting and/or stigmatized body was looking at it with a historically contingent mindset. ${ }^{38}$ In the case of the stigmatics, two aspects seem to have influenced their perception

33 “[...] mais ce qui se passait pendant les extases était bien différent. Chez Louise, il y avait une mise en scène étonnante, pleine d'émotion pour les spectateurs; plus d'une fois on a prononcé le mot de miraculeux," Leuven, Kadoc, Jezuïeten, Ludovicus Boeteman, anonymous report on a visit to a stigmatized Carmelite nun in 1851 and to Louise Lateau in 1869 .

34 See Chapter 1.

35 Herzig, "Stigmatized holy women," 171; Zarri, "Lucia da Narni;" Herzig, "Christ transformed."

36 "Nonne Lucia" of Ferrara, Pascal, "Nichts Neues," Hermann. Zeitschrift von und für Westfalen, 44. Stück, Hagen, 30.1817, 352.

37 Gooldin, "Fasting women," 32.

38 Many of the stigmatics reported in the nineteenth and early twentieth century were famous for their inedia (e.g. Louise Lateau and Therese Neumann). It seems that the visible stigmata and ecstatic embodiment of Christ's Passion are what drew thousands of people to their bedsides, rather than their ability to go without food (apart from the Eucharist). 
or the "gaze": ideas about the miraculous and wonder; and the cult of suffering (addressed more elaborately below).

Here, it is important to recall what Nils Freytag and Diethard Sawicki remarked about the pilgrims visiting Maria von Mörl. Rather than a visit to a long-established religious site, the main incentive for such trips was the ambition to experience real miraculous and spectacular events. These visions and strange corporeal phenomena documented the continuing existence of miracles. ${ }^{39}$ Nevertheless, even in the case of von Mörl, there were resemblances with more traditional sites. As Elke Pahud de Mortanges has noted concerning the bodily comportment of von Mörl, her semi-floating stance, the way in which she presented herself, was in itself enough to turn her into a devotional image ("Andachtsbild"). ${ }^{40}$ Having the opportunity to carefully observe the stigmatic was of central importance to the visitors and, as the quote by the Emmerick visitor above illustrates, touching was also significant. The fragment describes how during a visit to the stigmatic in 1812 he touched her hands and feet and felt that they were ice cold and truly bleeding. Here, touch was an extension of the eye. ${ }^{41}$

It is not difficult to see how visibility had its downsides. More than one stigmatic was accused of putting on a show and faking their reliving of Christ's Passion in order to draw attention and create a commotion. ${ }^{42}$ Even in the cases where the good faith of the stigmatic was not under discussion, allowing yourself to be gazed at was deemed problematic. How could it be reconciled with the ideal of humility? A case in point is Louise Lateau. In a letter to the Archbishop, a contemporary complained that her parish priest had gone to Bois-d'Haine and - as many others - had attended the Holy Communion of Lateau. "Should one not forbid that? [...] Long live the hidden life! How could L. not understand that and why has she not retired to a convent but instead surrendered herself to the gaze of men ("regards des hommes")?"43 The letter

Older cases of combined inedia and stigmatization include: Elisabeth van Spaalbeek, Catherine of Siena and Veronica Giuliani, Lamot, "De heilige honger."

39 Freytag and Sawicki, "Verzauberte Moderne," 17.

$40 \quad$ Pahud de Mortanges, "Fromm," 169.

41 We will discuss other aspects of the tactile experience in greater detail in Chapter 5 on material culture. On the importance of all the senses for the religious experience, see Macdonald, Murphy and Swann, Sensing, 3.

See the comments on Anna Perschl, AEM. Realia 923 a. Erscheinungen - Einzelfälle 18391845, Perschl, letter of Pfarrer Joseph Ostner to the Archbishop, 29 February 1840, "dass mir das ganze wie eine geistliche Komödie, als eine Profanation des heiligsten vorgekommen sey," - "Aufsehen zu machen."

43 "Ne devrait-on pas défendre cela? [...] vive la vie cachée! [...] ne s'est-elle pas retirée dans un couvent pour être délivrée des regards des hommes?" Archives of the Congregation 
writer struck a nerve here for it was indeed a female body that was put on display in a public setting. Lateau's body was thereby not the only exceptional body to be scrutinized by medical experts (as were the bodies of the hysterics in La Salpêtrière), ${ }^{44}$ or gazed at by the curious (as with other spectacles or fantasies) and the faithful (as with the bodies of those miraculously cured in Lourdes). ${ }^{45}$

Throughout the period under discussion there was a change in the setting of this public observation that needs to be highlighted here. In her article on stigmatic cults and pilgrimage, Paula Kane studied the cases of Emmerick, Lateau and Therese Neumann $(1898-1962,1926)$ and noted how the nature of such visits changed, evolving from an "intimate encounter to a public spectacle." ${ }^{46}$ She described how "the intimate duo of Brentano and Emmerich gave way to the tableau of Lateau surrounded by dozens of doctors, scientists, and journalists, which was succeeded by the immense weekly crowds at Konnersreuth who came to seem more touristic than spiritual." ${ }^{47}$ The setting, the number of visitors, the visibility and types of wounds, the way the Passion was embodied - all these factors could differ from one stigmatic to another and all had an influence on the way in which the devotees experienced their visit.

The visibility of their bodies was tied up with the "proof" status of the stigmata, as discussed above. As Barbara Vinken has summarized it: as these bodies became "the laboratory of science," they also became the "stage of the Passion play."48 We will address what this Passion play was precisely comprised of and what effect it had on the visitors in the next section. Here, it is important to note that because of this "evidence" aspect, the ways in which and the accurateness with which this Passion play was performed, was also the object of scrutiny. As Sigal Gooldin remarked on the fasting women, "the ways in which one offers up 'the body/the self' to public consumption" were "assessed on

for the Doctrine of Faith (ACDF), Archivum Sancti Officii Romani (so), Stanza Storica (St.St.), Lateau $\mathrm{C}_{4} \mathrm{~F}$ 1, report by Du Rousseaux, "Louise Lateau" Ctsse de Liminghe, 26/6/1883, from Gesves par Assesse, Introductory letter from Du Rousseaux, 3 August 1883 added to a letter by Mgr Du Rousseaux, 4 August 1883.

44 Didi-Huberman, Invention.

45 Kaufman, Consuming Visions, 139, 154; see also Harris, "Les miraculées."

46 Kane, "Stigmatic cults," 122.

47 Kane, "Stigmatic cults," 124.

48 "Ihre Körper wurden, wie sie zum Labor der Wissenschaft wurden, zur Bühne eines Passionsspiels." Vinken, "Via crucis," 22. She refers to "der experimentelle Furor" and the female body under the male gaze (of the priest and of the medical expert) (23). Menke refers to the female body as a "stage of evidence" ("Bühne der Evidenz"), Menke, "Nachträglichkeiten," 34 . 
the adequacy of the performance" and relied on the gaze of the spectators. ${ }^{49}$ When Elisabeth Bartenhauser (1813-?, c. 1840), a stigmatic from the region of Oberbayern, made some "movements that were historically inaccurate at the very the least," her pastor asked her not to perform such movements again and not to do anything that "did not match the biblical narrative."50

\section{The Meaning of Suffering}

\subsection{The Cult of Suffering}

Considering the existence of crucifixes, paintings of martyrs and the Mater dolorosa, the average Catholic of the nineteenth century would have looked at broken, suffering bodies and regarded them as meaningful. The nineteenth century witnessed a revival, or rather a reinvention, of a medieval devotional culture in which the suffering of Christ played a central role. The popularity of stigmatics in this period might be linked to this Christocentric emphasis. There was, however, a clear difference in tone: with its focus on the corporeal, the nineteenth-century "popular" mysticism that the stigmatics embodied was not similar to the intellectual (bridal and passion) mysticism of the Middle Ages. ${ }^{51}$

With an emphasis on the suffering Christ, the devotional context of the modern stigmatics was similar to that of the reports of stigmata in even earlier ages. Throughout the centuries, stigmatization has been associated with the rise and reinvention of a type of spirituality that emphasized the imitatio Christi and compassion. ${ }^{52}$ St Francis's stigmata (1224), for example, were reported at a time when the cult of the suffering, human Christ had become more popular, and inspired religious practices that aimed at more active participation

49 Gooldin, "Fasting women," 36. On the careful monitoring of the movements of Louise Lateau (on 18 December 1869) by the pastor of Braine-l'Alleud, Ad. Hoofs, see Anonymous, Louisa Lateau of de kruiswonddragende van Bois-d'Haine, 7-8.

50 "Bewegungen bemerkt hatte, die wenigstens historisch ungetreu sind, so ermahnt ich sie, jener Bewegungen, und überhaupt Alles zu unterlassen, was von der biblischen Erzählung abweicht." AEM (AEM), Realia 923 a Erscheinungen-Einzelfälle 1839-1845, Bartenhauser, letter to the Archbishop, 11 September 1840, Pfarrer Mathias Weinzierl.

$5^{1} \quad$ On the difference in emphasis, see Priesching, "Mystikerinnen," 97.

$5^{2}$ Von Tippelskirch, "Ma fille," 264, "Un contexte de méditation religieuse ainsi qu'une remémoration de la Passion du Christ - et ceci sur deux niveaux: d'une part, les lecteurs et lectrices de ces compte rendus en viennent à savoir que les stigmatisés s'étaient préparés à leurs expériences grâce à ces méditations, d'autre part ce contexte influence de manière décisive la réception de ces comptes rendus." 
in his suffering (e.g. through ascetic exercises). ${ }^{53}$ Stigmatics of the fifteenthcentury in the Rheno-Flemish area have been linked to the rise of the Devotio Moderna that had Christ's Passion as its primal focus point, ${ }^{54}$ while the Italian stigmatized "sante vive" ("living saints") of the sixteenth century reflect a Catholic revivalist culture that lauded suffering, self-flagellation and starvation, which can be found in the biographies of devout women. ${ }^{55}$ Similarly, the nineteenth century witnessed a rise in Christocentric devotions that emphasized his Passion, such as the Eucharistic devotions, the cult of the Sacred Heart and that of the Immaculate Heart of Mary, as well as religious practices such as praying the Stations of the Cross, meditations on the five wounds of Christ and praying the rosary (with the dolorous mysteries). ${ }^{56}$ The emphasis in these devotions was on the suffering rather than the triumphant Christ.

There was a logic to the suffering, as Thomas Kselman remarked: "the prayers and suffering of those who believed could compensate for those who did not." This need to compensate was felt to be more urgent at a time in which secularization seemed to be increasing. ${ }^{57}$ Moreover, Rome had added three women who carried the stigmata to the number of blessed and canonized: Veronica Giuliani was canonized in 1839; Maria Francesca of the Five Wounds of Our Lord Jesus Christ was beatified in 1843 and canonized in 1867 , and the canonization of Claire de Montefalco took place in $1881 .{ }^{58}$ Whilst popular perceptions of sanctity ("living saints") and official sanctity (beatification and sanctification) continued to differ (see Chapter 7), the

53 On the emergence of a more emphatic Imitatio Christi in the eleventh and twelfth centuries as the foundation of St Francis's spirituality, see Klaniczay, "Illness," 119; Adnès, "Stigmates," c. 1213 and e.g. the Jesuit scholar J.H. Crehan, in his introduction to Herbert Thurston, Surprising Mystics (1955), x. On this active imitation of Christ's suffering, sometimes even leading to self-mutilation (e.g. Marie d'Oignies, 1177-1213, who wanted to share Christ's wounds), see Klaniczay, "Stigmatisierung," 139; Klaniczay, "Bodily signs," 30; Lochrie, Margery Kempe, 14; and Roodenburg (on the late-medieval pathopoiea), "Empathy."

54 Bouflet, Les stigmatisés, 41 and Cruz González, "Beyond the Bride," 107.

55 Mouchel, Lesfemmes, 8-16. He emphasizes how the tone of this genre differed from that of the Bulls of the Church, the sermons and paintings, where one would find a far more cautious approach. See also Bouflet, Les stigmatisés, 43. On how this trend in female stigmatics can be linked to the more democratic perception of stigmatization and participation in Christ's suffering among late medieval Dominicans (in contrast to Franciscans, who insisted on the uniqueness of St Francis), see Klaniczay, "Illness," 135; Zarri, Le sante vive.

56 Schulze, "Die 'angeblich' stigmatisierte," 168; Corbin, “Lemprise," 55; Priesching, Maria von Mörl, 83 .

57 We will discuss this in more detail in the next section, Kselman, Miracles, 103.

$5^{8}$ Klaniczay, “Louise Lateau," 290. 
devotional context and knowledge of such older cases of stigmatization had an impact on modern stigmatics.

Observing a suffering body (Christ's) was an accepted practice - as was the ideal of the imitatio Christi. The report on the stigmatized Carmelite nun in Tournai (Belgium, 1851), as noted above, described how the nun had been seen "absorbed in prayer" before a crucifix that was capable of "seizing a pious soul." Next to the cross, the author observed a "frame on which the stigmata of a saint were emphatically printed in red." ${ }^{\prime 59}$ According to the author, the nun was sent away to another cloister and recovered in this healthier environment, the stigmata disappeared and she subsequently returned to her old cloister. Religious practices like this were not solely the domain of women religious in the mid-nineteenth century, as the following two examples from Germany show. Particularly telling is the story of Karoline Beller (1830-1863), the young girl from Lütgeneder who displayed the stigmata in May $1845 .{ }^{60}$ When she started to draw the attention of the press and visitors, she was isolated in a hospital and eventually confessed to being a fraud. A Vincentian nun at the institute to which the stigmatic was brought, told how the young girl had started to deceive everyone, claiming that Beller built on her prayer experiences:

She simply told me that when she was a child, during the procession of Sacrament's day, she and the other children had to recite poems related to the H. Sacrament with outstretched arms in front of the different altars. Ambition triggered her to do this in the most solemn way possible. She would then kneel in the hayloft and elsewhere, working herself into a higher state of tension. She continued to do this even after she had left school, and she became increasingly better at it. ${ }^{61}$

59 "absorbée dans la prière", "propre à saisir une âme pieuse", "un cadre dans lequel étaient fortement imprimés en rouge les stigmates de quelque sainte." Leuven, Kadoc, Jezuïeten, Ludovicus Boeteman, anonymous report on a visit to a stigmatized Carmelite nun in 1851 and to Louise Lateau in 1869 .

6o On the popularity of Karoline Beller and the eventual discovery that she was a fraud, see Muhs, "Die Stigmata."

61 "Sie teilte mir einfach mit, sie habe als Kind bei der Fronleichnamsprozession mit anderen Kindern vor den verschiedenen Altären mit ausgebreiteten Armen Gedichte, die sich auf 's hl. Sakrament bezogen, aufsagen müssen. Der Ehrgeiz habe sie gestachelt, möglichst feierlich das zu tun. Da habe sie denn auf dem Heuboden und sonst umhergekniet, sich ganz in eine höhere Spannung hineinarbeitend. Das habe sie denn auch noch viel getan, als sie der Schule schon entlassen gewesen, und sie habe sie es immer mehr gelernt." Erzbistumsarchiv Paderborn (E BAP), Acta Specialia. Pfarrstelle zu Lütgeneder, Bd.I. 18271939, Bericht der Vinzenzianerin Theodora an den Pfarrer Happe in Lütgeneder über die 
When her parish priest showed Beller an image of St Catherine of Siena and told her about the stigmata and her life, she wished she could become "a saint like that." When she became ill (some sort of cramping in her spine, cataleptic attacks) she continued her prayer practices with outstretched arms and various gesticulations and realized that this "cramp" allowed her to be in complete control of herself ("Sinne"), so she started to maintain these prayer positions when others entered her room. Finally, when their housekeeper remarked, "My God, the only thing that is still missing is the holy wounds," she started to create them herself. ${ }^{62}$

The fear of negative influence through the examples of famous stigmatics and an exaggeration of corporeal religious practices also echoes through the reports on other cases. We see a distrust in excessive devotional and ascetic enthusiasm in the list of questions that Pastor Weinzierl had to answer concerning the case of Teresia Taubenberger (?-?, c.1839) in 1842. He protested vehemently against accusations that he had led some women to a hypertensive ("überspannten") religiosity and to petty devotions ("Andächteley"). $\mathrm{He}$ claimed that he had never singled her out for religious teachings, that he had actually discouraged Taubenberger from going to confession so often, and as soon as he found out that she was using the cilicium and flogging lash, he forbade it. Moreover, on hearing someone state that she wanted to visit Maria von Mörl, he advised against it. ${ }^{63}$

In all three mid-nineteenth-century cases (the Carmelite nun, Beller and Taubenberger), the reports about these women refer to the alleged stigmatic's knowledge of famous - imitable - predecessors. Moreover, these sources

angeblich stigmatisirte Caroline Beller in Lütgeneder 1863 (1846), typed copy of an original from 1863 (Bericht der Vinzenzianerin Theodora).

62 "Mein Gott, es fehlt doch nichts als die hl. Wunden." ввAP, Acta Specialia. Pfarrstelle zu Lütgeneder, Bd.I. 1827-1939, Bericht der Vinzenzianerin Theodora. See also the medical report in which the physician noted how: "Only the stigmata were missing. They were wished for, intensely desired and since they did not appear, created" ("Nur die Stigmata fehlen. Sie werden gewünscht, inbrünstig verlangt, und da sie nicht erscheinen wollen, gemacht."), Berlin, Geheimes Staatsarchiv, Preussischer Kulturbesitz (GStAPK), I.HA Rep.76. Kultusministerium viII A Nr.218o: Acta betreffend die angeblichen WunderKuren und Wunder-Krankheiten, 1821 Nov. 1904 Jan, report of Kreisphysikus Pieper, 6 June 1845 .

63 AEM, Realia 923 a Erscheinungen-Einzelfälle 1839-1845, Bartenhauser, report of the dean of Osternwargau to the episcopal ordinariat, 13/12/1842 on the behaviour of Pastor Weinzierl. On accusations of creating a mystical atmosphere, see also: Kickertz and Flesch (1878). On Taubenberger, see: Gisibl, Frömmigkeit, passim. On the influence of the Franciscan father Heinrich Gossler in the case of Theresia Winter (1845), see Schulze, "Die 'angeblich' stigmatisierte," 144. On the fear of exaggeration of religious practices such as flagellation, see Corbin, "L'emprise," 75. 
document a fear of an exaggerated, unhealthy, religious atmosphere not seldom thought to be created by the parish priest, her father confessor. ${ }^{64}$ Apart from the distrust that emerges from these references, we also gain a glimpse of how religious practices focusing on the Passion of Christ, suffering and atonement called for specific "body techniques" 65 that could eventually - as in the case of Beller - be incorporated into the stigmatic's embodiment of Christ's Passion. Nevertheless, while there was a certain "common" devotional language and a list of stigmatized predecessors that could be referred to, each stigmatic functioned within a specific religious setting, which had its local preferences and emphasis depending, for example, on the presence of other denominations in the region. ${ }^{66}$

\subsection{Redemptive Suffering}

Pain is a subjective experience and a cultural construction, and how it is interpreted depends on the historical context. ${ }^{67}$ Within Catholic and Protestant versions of Christianity, pain is equipped with a divine purpose. In her study on the history of pain, Joanna Bourke mentions, among other forms: "pain as the result of sin, a guide to virtuous behaviour, a stimulus to personal development, and a means of salvation." ${ }^{\prime 8}$ Since the stigmatics were reliving Christ's Passion, their pain was a cleansing and reparatory suffering, through which they were atoning for the sins of others. ${ }^{69}$

The bodily movements and facial expressions of the stigmatic were carefully observed by the visitors and - if necessary - explained by a bystander (e.g. a supportive parish priest who explained which part of the Passion the visitors were witnessing). As we saw above, Elisabeth Bartenhauser failed to imitate

\footnotetext{
64 Muhs, "Die Stigmata," 104, 119.

65 von Tippelskirch, "Schmerzen," 154.

66 For a more general reflection on the specificity of the devotional context, see e.g. the work of Mary Heimann on the limits of uniformization: Heimann, "Catholic revivalism;" and her work on the reception of the English stigmatic Theresa Higginson: Heimann, "Medical and mystical opinion."

67 Or, as Louise Hide, Joanna Bourke and Carmen Mangion stated, "Pain has meaning, which is formed out of the complex interactions taking place between the body, mind and culture. As a result, it differs from person to person, social group to social group, and it changes over time and space. It is profoundly influenced by personal beliefs as well as social mores and temporal contexts," Hide, Bourke, Mangion, "Introduction," 1; Bourke, The story of pain, 6-8, 12; Boddice, "Introduction," 2; von Tippelskirch, "Schmerzen," 145; Moscoso, Pain, 2.

68 Bourke, The story of pain, 91; Kane, "She offered," 87, "At least since the late Middle Ages, therefore, pain was something to be interpreted variously by Catholics as a punishment for sin, a trial from God, or a vehicle for transcendence."

69 Albert, Le sang, 332; Kselman, Miracles, 103.
} 
Christ's Passion accurately. In the case of Maria Fiechtner (cited above), who never developed visible stigmata and remained unknown, the resemblance of the timing of her corporeal phenomena to the Passion timeline itself threatened to give her away. Her parish priest noted that because he was visiting her on Thursdays and Fridays people in the village might start speculating and conclude that there might be a stigmatic in the house. The villagers were already familiar with the phenomena, as Bartenhauser, who was from the same region and was supervised by the same parish priest, went into ecstasy every Thursday evening when the church bells tolled "the fear of Christ" ("die Angst Christi lautet"). ${ }^{70}$

The Biblical rhythm of suffering not only played a part on the hourly level. In some cases, suffering was thought to appear or increase on Catholic feast days linked to Christ's Passion (such as Holy Week, the Discovery of the Holy Cross) or St Francis (17 September, the day he received the stigmata). ${ }^{71}$ The report on the anonymous Carmelite nun from Tournai mentioned that it was primarily during Holy Week and on some feast days related to the Passion that one could observe the marvellous effects. ${ }^{72}$ While the initial point of reference was Christ's suffering, the pain the stigmatic showed could symbolize more than this. The intensity of the pain was thought to be closely linked to the liturgical calendar, ${ }^{73}$ and to current political events concerning the Catholic Church. In other words, the bodies of the stigmatics not only referred to that of Christ and of stigmatized predecessors, but also symbolized the current state of society - they referred to both the past and the present. ${ }^{74}$

It is important to emphasize this latter aspect for, as Nicole Priesching has noted, "Even when mysticism in itself is timeless - since it is ultimately about

70 AEM, Realia 923a, Erscheinungen-Einzelfälle, 1839-1845, Bartenhauser, letter to the Archbishop from Pfarrer Mathias Weinzierl, 10 January 1840; idem, 6 October 1841, on Weinzierl's visits on Thursdays and Fridays; report of Dechant Gilbert Niedermayer to the Archbishop: the lights in the room were on until midnight, so people might have started guessing.

71 See the report on Maria Beatrix Schuhmann (stigmata 1853), Archiv des Bistums Passau (АВP) OA Varia I 17b II, correspondence box 2, letter of Seidl to Stadtkooperator, 15/7/1891; the report on Anna Maria Göbl, Priller, 1928, 6o.

72 "C'était pendant la semaine sainte surtout et à quelques fêtes de la Passion qu'on observait ces effets merveilleux," Kadoc, Jezuïeten, Ludovicus Boeteman, anonymous report on a visit to a stigmatized Carmelite nun in 1851 and to Louise Lateau in 1869.

73 Goslicka, Die Kraft, 62, "[...] Stigmatisation ist immer auch Wiederholung sozusagen reenactment: des Lebens und der Passion Christ, der Abläufe der liturgischen und persönlichen Glaubenspraxis, der stigmatisierten Vorgängerinnen und Vorgänger."

74 They followed different time patterns: linear (echoing Christ and precursors) and referring to the present-day, and circular (liturgical calendar). In this respect, they are in fact the embodiment of the complexity of the experience of time as described by e.g. Wiesner-Hanks, "Introduction," 15. 
the experience of what is beyond time ("des Überzeitlichen") - the mystics themselves are not at all [timeless]." ${ }^{\prime 7}$ The roles they may take on and their interpretation depend on the historical setting. This historicity also had its effect on the devotees' perception of the reparatory suffering. While the main idea - stigmatics atoning for the sins of others - more or less remained the same, what these women were suffering for changed. It is not possible to give a complete overview of all the causes with which the stigmatics have been associated, but it is easy to determine the major concerns of Catholics throughout the period by scanning the readings of their bodies. Some Belgian examples might illustrate this.

Louise Lateau's suffering, for example, was said to have increased when the Roman States were under attack (September 1870), and during the profanations in Paris during Holy Week (1871). ${ }^{76}$ Moreover, her pain was linked to that of the German Catholics, who were suffering under the anti-Catholic laws in the newly developing (Bismarckian, Protestant) German nation. Tellingly, some small booklets about her carried the title "Trostbüchlein" (Book of Comfort) for German Catholics. ${ }^{77}$ Similarly, the Belgian stigmatic Clara Jung (1887-1952, stigmata 1939) was regarded as a "peace offering" ("zoenoffer") for the horrors of the Second World War, ${ }^{78}$ while the outcome of the Great War was due to Lucie Schmit-Klaer (1854-1924, stigmata 1916), at least according to her supporters. ${ }^{79}$

The political meaning of stigmatics will be discussed more elaborately in Chapter $6{ }^{80}$ For our analysis here, it is important to note that in relation to the

75 "Auch wenn Mystik an und für sich zeitlos ist - es geht schließlich um die Erfahrung des Überzeitlichen - so sind es die Mystiker keineswegs. Sie sind vielmehr geprägt von den Erfahrungsräumen und Deutungsangeboten ihrer Gesellschaft. Sie übernehmen bewusst oder unbewusst je nach den Zeitumständen andere Rollen, werden auch anders inszeniert, drücken sich anders aus," Priesching, "Mystikerinnen," 79-80.

76 Van Looy, Biographie, 155; Thiéry, Nouvelle Biographie, vol. 2, 458-461; and vol. 3.2, 535 .

77 Anonymous, Ein Besuch bei Louise Lateau $\left(1874^{2}\right)$; Rebbert, Anna Katharina Emmerick (1878).

78 Borsbeek, Docc, 245.7 Jung, Vijfentwintigste verjaardag van het overlijden van de gestigmatiseerde Clara Jung (20 May 1952-2o May 1977).

79 "Quel est le St François, le St Bernard qui nous fera comprendre et aimer la douleur? Qui sait si nous n'avons pas dû la victoire de 1918 à quelque stigmatisée inconnue, dans un cloître ignoré! Wallery-Radot La vie de souffrance de Madame Klaer, cloîtrée dans le mystère de sa solitude, répond à cette question. Une victime choisie par Dieu pour le salut du monde." Archief Aartsbisdom Mechelen (AAM), Verschijningen, 2o. Lucie Schmit-Klaer, new manuscript of 'Vie de Madame Klaer, glorieuse servante de Dieu', 1926?

$80 \quad$ See also Albert, Le sang, 343, "Ainsi au XIX ${ }^{\mathrm{e}}$ siècle, dans le contexte de l'émergence des nationalismes modernes, n'est-il pas rare de voir des stigmatisées considérées comme des victimes 'nationales', dont les souffrances préservent un peuple de catastrophes politiques ou militaires." 
various political events, the visible, bleeding stigmata and the suffering body of the stigmatic could function as a signpost in different ways. For Catholics in despair, it could be a sign of divine intervention, God's continuing presence, the 'truth' of their faith - in short, a beacon of hope. At the same time, the intensity of the suffering showed how much was wrong with the world, observing the body in pain inspired shame for the wrongs that had been committed against God and his Church. Interestingly, in order to be perceived as an expiatory victim, the life of a stigmatic had to be regarded as free of any blemish. ${ }^{81}$ In other words, while the "sanctity" (on a non-official level) of the stigmatics was linked to their visible wounds - the idea of the saint as token - ideally, they also lived an exemplary life.

\subsection{Observing the Body in Pain: The Gender of Suffering}

Historians such as Paula Kane, working on the ideal of reparatory suffering, sacrifice and the heroic victim in the nineteenth century, have pointed out how these ideals were closely linked to ideals of femininity and the sacrifices women made on behalf of others. Suffering corporeally (whether self-inflicted, e.g. by fasting; or not, e.g. through illness) allowed these women to help others - they atoned for the sins of their fellow human beings. As Kane notes, "[o]bedient submission to suffering, rather than the suffering itself, is the redemptive act, in imitation of Christ's complete acceptance of God's will." ${ }^{22}$ Tellingly, stigmatics were described in terms related to this exhibition of patience in suffering. The German words "Leiderin" and "Dulderin," 83 and the Italian "Paziente" and "addolorata" denote women who patiently accepted and suffered through the pain that God had been willing to send them. ${ }^{84}$ They were not only stigmatics. The term "Dulderin" seems to have had a broader meaning, referring to all women who suffered their hardships with serenity ("Gelassenheit"). ${ }^{85}$ Moreover, even within a religious setting, the term could be used for women who did not carry the wounds of Christ but did suffer through illnesses in the belief that it was God's will and their pain had meaning. ${ }^{86}$

In the case of the stigmatics, the words that were linked to their pain and suffering also referred to the Christian teachings on atonement. For example,

\footnotetext{
$81 \quad$ Albert, Le sang, 338.

82 Kane, "She offered," 83. See also Kselman, Miracles, 102; Burton, Holy Tears.

83 See e.g. Anna Schäffer (1882-1925) who was also called the "Dulderin von Mindelstetten."

84 See e.g. Talbot, Letter from the Earl of Shrewsbury (1841); Anonymous, Ristretto della vita di Maria Domenica Lazzari di Capriana (1840).

85 See e.g. definition in Adelung, Grammatisch-kritisches Wörterbuch, 1570.

86 See e.g. Ana Nasl called "Dulderin" and "Eine Sühneseele im Geiste der heiligen Theresia vom Kinde Jesu," вsв, Nachlass Lama, Friedrich von (1876-1944), Ana 445, file 2.
} 
stigmatics were described as "Sühneseele" and "Opferseele." These nouns hint at the sacrifices the women made to appease the anger of God, to atone for the sins committed by humankind. The ideal of sacrifice was embedded in ideals of Catholic femininity and sanctity. ${ }^{87}$ As one contemporary recalled a few years after the death of Anna Katherina Emmerick: "She suffered and atoned for the debt ("Schuld") of others and therefore also the sad and needy went to her." She had suffered through everything "as a saintly patient" with "the greatest patience." 88

In the nineteenth century, as women were associated with their bodies, rather than the mind (as men were), it seemed to make sense to their contemporaries that their religious enthusiasm could find its expression through their bodies. ${ }^{89}$ Nevertheless, as noted above in the discussion of the public setting of the spectacle of stigmatization, the femaleness of the body added to the unease about its visibility. However, when we look at the descriptions of the stigmatic's body during the Passion, it is useful to recall what Grietje Dreesen has noted about medieval female mystics. She writes that while she agrees with Caroline Walker Bynum that these women often sought access to the divine via the human Christ and had a preference for corporeal experiences and expressions: a unison with his suffering meant an imitation of his exemplary (sinless) humanity and of his salutary suffering, and thus required the removal of all the attachments of the "flesh" that were linked to the original sin and of which the threat had been removed through the suffering, dying and resurrection of Christ (in his role as Saviour).

In other words, the "new flesh" was not female flesh and the salutary blood was not female blood - it was a rebirth in Christ. ${ }^{90}$ The visitors may have been

$87 \quad$ Kane, "She offered."

88 "Sie hat gelitten und gesühnet für fremde Schuld darum sind auch Traurige und Hilfsbedürftige zu ihr gegangen", "wie eine heilige Dulderin", "der größten Geduld," BAм, Emmerick/Hensel, 40. Stimmen, Abschrift aus No. 41; 81 S., alte Sign. IV.6, Theresia Uckelmann, 68 Jahre, geb. zu Dülmen 1824, Lehrerin in Warendorf, 31-36.

89 Weiß, "Stigmata," 119. While it is difficult to retrace how the ideal of women's somatic piety evolved throughout the centuries, scholars such as Monique Scheer, Nicole Priesching and Waltraud Pulz have shown that the nineteenth century witnessed a revival, if not the invention of, corporeal religion. Pulz, "Vorbemerkung," 7-10; Scheer, "Das Medium;" Priesching, "Mystikerinnen."

$90 \quad$ "Vereniging met Christus en zijn lijden betekende echter navolging van zijn voorbeeldige (zondeloze) menselijkheid en van zijn verlossend lijden, en vroeg dus allereerst om een afleggen van de gehechtheden van het 'vlees' die door de erfzonde waren ontstaan en waarvan de doem door het lijden, sterven en opstaan van Christus in principe was losgemaakt (daarin bestond juist zijn Verlosser-zijn)," Dresen, "Is dit mijn lichaam," 86 and 101. 
looking at a female body but they were gazing at something that represented other bodies, someone else's pain - Christ's obviously, but not solely.

Reports on the visits to the stigmatics warn us to be wary of an overly superficial reading of the female stigmatic's embodiment of Christ's Passion. One visitor to Lateau, for example, described his impressions as follows: "There is nothing more moving than seeing the young girl unmoving and silent, permanently in ecstasy and in some way showing the facial features of the mother of sadness, as she has been depicted by one of our greatest painters. ${ }^{\prime 11}$ In other words, for this observer, Lateau also incarnated the Mater dolorosa - the weeping Virgin at the foot of the Cross. Such references encourage us to have a more open view about the visitors' perceptions of the stigmatics (they did not solely see Christ) and on suffering: it was not only Christ's suffering that was of importance; it was not only his corporeal and emotional pain (e.g. of feeling abandoned by God) that was relevant, but also Mary's pain, as a mother who suffered her son's pain. Her compassion is as painful for the onlooker as the pain of the Son..$^{92}$

The images evoked here are important. To ensure their readers understood what they were seeing, writers used images that were familiar to them from the Catholic culture of suffering. Thus, while, for example, the tears on the face of the stigmatic could have remained gender neutral, some of the writers chose to link them to the sorrow of the Virgin (in its pictorial rendering as the Mater dolorosa, or the literary equivalent, the Stabat Mater). ${ }^{93}$ The type of suffering described, defined the gendered image that was adopted: in the descriptions of emotional compassionate pain, the Mater dolorosa was the point of reference; while in the elaborations of the physical horror, it was Christ on the Cross. ${ }^{94}$

Thus, when the banned Prussian priest, Fox, attempted to explain to his readers what he was seeing, he described Louise Lateau as a combination of the suffering son and his weeping mother: "Everything was calm and still, everyone was moved, for in Louise one could see the suffering Saviour and the

91 "Ook is er niets aandoenlijker dan het jong meisje onbeweeglijk en stilzwijgend, gestadig in opgetogenheid te zien en eeniger wijze de gelaatstrekken verbeeldende van die moeder van droefheid, gelijk zij door eenen onzer grootste schilders is afgemaald geweest," Anonymous, Louisa Lateau of de kruiswonddragende van Bois-d'Haine, 8.

92 Van Osselaer, "Dor."

93 E.g. even citing the thirteenth-century poem, Stabat Mater (about the sorrows of the Virgin at the foot of the Cross). For a similar reference concerning Therese Neumann, see Staudinger, Die Leidensblume, 5 ; on an anonymous stigmatic from D. (1929).

94 See e.g. comments on Barbara Pfister: "Bei ihren Leidenszuständen was sie eine ganz andere, nicht mehr die Babet, sondern der sterbende Christus." Testimony of Maria Schmitt, 22 February 1939 in ABSp, Dokumentation Barbara Pfister, M7 Protokolle über Zeugenaussagen. 
aching mother at the same time. $\mathrm{O}$, what an image of suffering! I will never forget it." 95

In other words, stigmatics such as Lateau were suffering through Christ's physical and emotional pain and the Virgin's emotional pain - they were at the pinnacle of suffering. Thus, there seems to have been no clear-cut gender shift (to Christ's suffering body). The visitors could see them as gendered images of pain, both with a male and a female point of reference. Such a combined image only makes sense if we regard the emotional suffering, the compassion, as being as important as the physical suffering. The visitors could see the body of the stigmatic as embodying both types of suffering: Lateau wept the Virgin's tears and bled through Christ's wounds.

[...] since for those with weak nerves and especially for women, looking at the spastic conditions can have very negative effects. ${ }^{96}$

I blame the death of my wife solely on the visit to Therese Neumann and I am certain that she would still be alive if she had not seen Therese Neumann. ${ }^{97}$

The fragments cited above were written more than 50 years apart, but both warned about the effect that a visit to a typical stigmatic could have on the viewer, and particularly on women. The suffering and blood could be too much and possibly have a disastrous effect on the nerves. Comparing these negative lines

95 "Alles war ruhig und still; jeder war ergriffen; den in Louise sah man den leidenden Heiland und die schmerzhafte Mutter zugleich. O, welch'ein Schmerzensbild! Nie werde ich dasselbe vergessen," Fox, Louise Lateau, 89.

96 "[...] da für Nervenschwache und besonders für Frauenzimmer das Anschauen dieser krampfhaften Zustanden sehr nachtheilige Folgen haben kann." "Aus Westphalen, den 12. August," Elberfelder Kreisblatt, 18 August 1846, 2-3; in a file on Theresia Winter (1846), Münster, Landesarchv NRW Abteilung Westfalen (Münster), Innere Verwaltung Oberpräsidium Münster. 123. Tätigkeit des Franziskanerpaters Henrich Gossler, no. 123.

97 "Ich führe den Tod meiner Frau ausschließlich auf den Besuch der Therese Neumann zurück und nehme bestimmt an, dass meine Frau noch am Leben wäre, wenn sie die Therese Neumann nicht gesehen hätte," StA, 13038 Regierung der Oberpfalz, Kammer des Innern, Polizei-Amt Bayreuth, 15 October 27: I. testimony of Nikolaus F. Similar: No. 7738 "Ins Referat 6." (Regensburg, den 8. März 1928 Referat 3), "Der Wiederausbruch ihrer geistige, Erkrankung ist demnach mit Sicherheit und der Tod mit grosser Wahrscheinlichkeit auf den Besuch bei der Therese Neumann zurückzuführen." 
to the testimonies that we studied above, it becomes clear that the Catholic devotees were indeed looking at the stigmatics, the suffering and the blood, in their own specific ways. They were trained in Catholic views on pain and well acquainted with a devotional culture in which a suffering body made sense. The pain of the stigmatics was meaningful to them because their bodies were regarded as miraculous, as "proof" of God's intervention.

Their exceptional bodies singled them out as "living saints" (with the saint as token) - whom Catholics could admire but not worship. At the same time, by focusing solely on the "wonder" we would overlook the referential quality of these "living crucifixes" 98 and only have a fragmented view of what the visitors were seeing. For them, the body of the stigmatic, the visible, bleeding wounds, had meaning and could even symbolize the state of society. The stigmatics, as Christ before them, were atoning for the sins of others.

The pain of the stigmatics not only had its effects on the level of the stigmatics themselves. Looking at their pain, as multiple sources on these visits testify, could have a "productive" effect on the visitors as well. Seeing the agony would call Christ's Passion to mind, generating shame for one's own sins, stimulating compassion and perhaps even encouraging people to change their lives. ${ }^{99}$ The pain of the stigmatics also had an edifying function for them; ideally, inspiring them to lead a better life. Some of the visitors wrote about their experiences and encouraged their readers to follow the example of the stigmatics - not physically, but emotionally. They might reflect on Christ's Passion through more traditional religious exercises, such as the contemplation of the crucifix or praying the stages of the Cross. Compassionate suffering was an ideal that all Catholics could attain. ${ }^{100}$

Thus, when Theodor Nolde wrote to the Belgian bishop in 1910, he already knew how to observe a stigmatic. He saw Christ in Rosalie Put, just as others had seen him in Louise Lateau and Anna Katherina Emmerick. For Nolde, the appeal of the suffering body was strong enough for him to cross the border, travelling from Germany to Belgium. As we will see in the next chapter, other Catholics made similar journeys.

98 Paraphrase of Paula Kane, "Stigmatic cults," 108.

99 We might say that the devotees shared an emotional community that had its own specific ideas on emotional suffering and compassion. On emotional communities, see Rosenwein, "Worrying," 824.

100 "Faire le chemin de la croix, honorer les souffrances du Christ, c'est aussi se procurer à soi-même soulagement et consolations dans les souffrances, les soucis et les peines. Car le Sauveur rend au centuple ce que l'on a fait pour lui," Waitz, Le message, 45. 


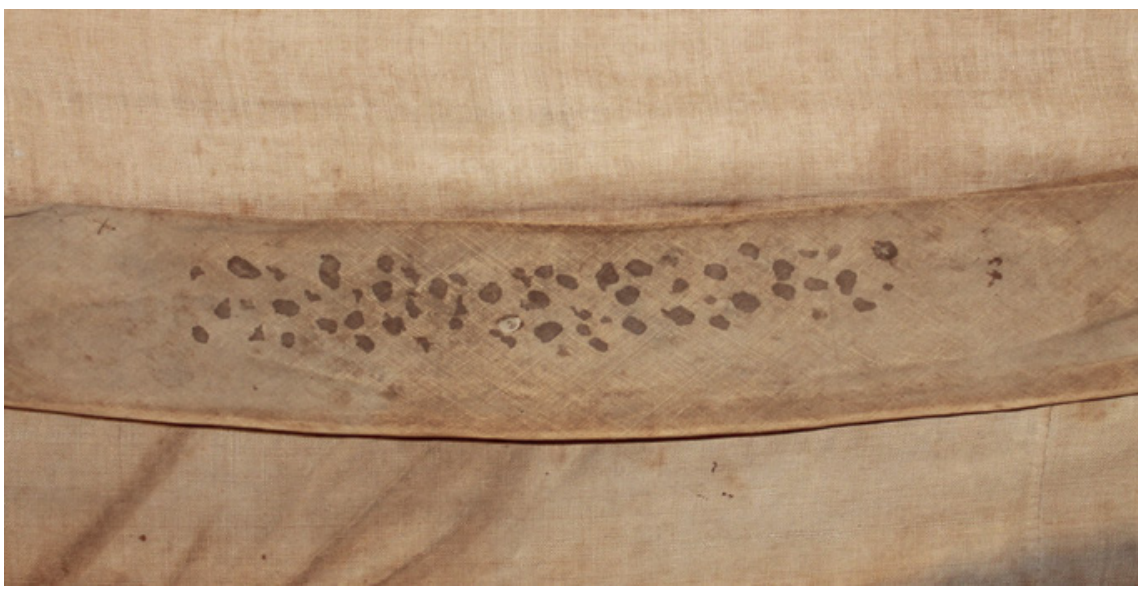

FIGURE 3.1 Bloodprint of the stigmata (crown of thorns) of Anna Katharina Emmerick. Dülmen, Gedenkstätte Anna Katharina Emmerick GEDENKSTÄTTE ANNA KATHARINA EMMERICK, (C) EMMERICK-BUND E. V., DÜLMEN

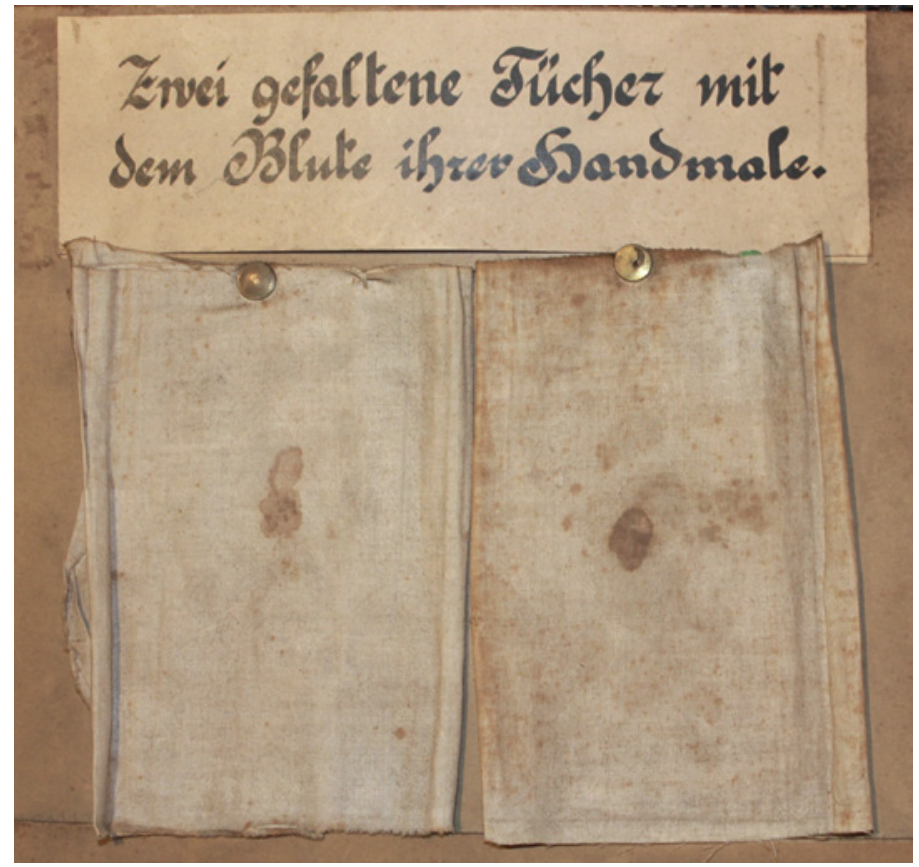

FIGURE 3.2 Bloodprint of the stigmata (hands) of Anna Katharina Emmerick. Dülmen, Gedenkstätte Anna Katharina Emmerick GEDENKSTÄTTE ANNA KATHARINA EMMERICK,

(C) EMMERICK-BUND E. V., DÜLMEN 